\title{
HERMENÊUTICA DA USUCAPIÁO FAMILIAR: ANÁLISE DOS PRESSUPOSTOS DA USUCAPIÃO FAMILIAR A PARTIR DE UMA INTERPRETAÇÁO SISTÊMICA
}

\author{
INTERPRETATION OF FAMILY “USUCAPIÃO”: \\ ANALYSIS OF THE REQUIREMENTS OF FAMILY "USUCAPIÃO” \\ ACCORDING TO A JOINT INTERPRETATION
}

HUGO RiOS BRETAS ${ }^{1}$

\section{RESUMO}

O instituto da usucapião verdadeiramente é nuclear para os Direitos Reais. 0 referido instituto é logrado tipicamente por meio de ação petitória, cujo propósito consiste na obtenção do direito real de propriedade, mediante a comprovação da qualificação possessória, isto é, da intenção de dono, prescrição aquisitiva e outros. De modo específico, em 2011, insurgiu a usucapião familiar, que exige para a sua configuração o abandono familiar, a posse exclusiva de dois anos e qualificada, além de o usucapiente não poder ser proprietário de outro imóvel urbano ou rural, respeitando ainda a localização do imóvel em zona urbana e que o imóvel não poderá sobejar a metragem de 250 metros quadrados. Ocorre que essa modalidade é alvo de múltiplas discussões doutrinárias e jurisprudenciais. Diante disso, o ponto melindroso deste trabalho não é outro senão a investigação a possibilidade de restringir esta modalidade ao abandono familiar ou se é defensável inserir outras hipóteses, em virtude de o ordenamento civil pátrio posicionar o abandono de lar ao lado de outras hipóteses similarmente nefastas, na. Assim, os estudos realizados nos permitem compreender que o abandono de lar exige o cúmulo do abandono do imóvel e da família. Noutro giro, a expressão "ex-cônjuge" ou "ex-companheiro" está ligada à situação fática de separação. Por derradeiro, o pressuposto de abandono é tão gravoso quanto outras hipóteses descritas no artigo 1573 do Código Civil, tais como a ofensa física ou moral, razão pela qual a usucapião familiar não deve se restringir ao abandono.

PALAVRAS-CHAVE: Usucapião. Abandono. Família. Cônjuges.

\section{ABSTRACT}

"Usucapião" really is fundamental to the Rights of things. This subject is achieved through action seeking property, and the purpose is to achieve the right of ownership, by proving the requirements, ie the intention to

\footnotetext{
1 Doutorando, mestre, pós-graduado e graduado em Direito pela Pontifícia Universidade Católica de Minas Gerais. Coordenador da Pós-graduação em Direito Público, Professor Adjunto da Escola de Direito, EAD, Extensão e Conteudista do Centro Universitário Newton Paiva. Coordenador das Pós-graduações em Direito Público, Constitucional e Ambiental, membro do Colegiado, Professor Adjunto da Graduação e Pós-graduaçao da FUNCESI. Professor das pós-graduações do SENAC, ANADEM (DF) e UNIASSELVI (SC). Advogado. hugorios.bretas@bol.com.br.
} 
own, term and others. Specifically, in 2011, family cancellation occurred, which requires that the family leave, the exclusive possession for two years, possession with all qualification requirements, and the author can not be the owner of another urban or rural property, also must have respect for the location of the property in urban area and the property can not exceed the measure of 250 meters. This is a subject that is full of doubt, in theory and in the tribals. Therefore, the difficult point of this work is the investigation into the possibility of reducing this species to family abandonment or if we can defend other hypotheses, because the Laws of Civil Law of Brazil place the abandonment of home alongside other equally complicated hypotheses in the Family right. The studies done let us understand that abandoning the home requires the sum of abandoning the home and family. In another matter, the word "ex-husband" has to do with the reality of the separation. Finally, the abandonment requirement is as serious as the other requirements of article 1573 of the Civil Code, for example, such as physical or moral aggression, therefore, the adverse possession of the family is only in the case of abandonment

KEYWORDS: "Usucapião”. Abandono. Família. Cônjuges.

\section{INTRODUÇÃO}

As mais distintas fontes do Direito pátrio comumente veiculam a extinção da culpa pelo divórcio. Em verdade, o fato é que esta discussão perdeu o seu furor no Direito de Família, sobretudo após a superveniência da Emenda Constitucional 66 de 2010, que teve o escopo de abolir os lapsos temporais mínimos para fins de dissolução do vínculo ou da sociedade conjugal. Contudo, após um ano da referida emenda, sobreveio certa instigação para a retomada desta discussão no Direito das Coisas, em decorrência da Lei 12.424 de 2011, em razão da inserção da nova modalidade de usucapião, qual seja, a usucapião familiar, cujo pressuposto basilar consiste na prova, por parte do usucapiente, do abandono de lar (hipótese histórica de culpa² pelo divórcio, nos termos do artigo 1573, IV do Código Civil de 2002).

Nesse ponto, emerge a angústia deste trabalho, a partir da identificação da "mens legis" que iluminou a mente do legislador. Ora, o cônjuge "agente da relação material matrimonial" sofrerá nefasta consequência patrimonial, que consistirá na perda da parcela de propriedade que lhe era peculiar (em condomínio com o cônjuge abandonado), em razão da reprovável conduta de abandono. Nesse discurso, reputamos sistemicamente que o abandono de lar na seara conjugal encontra hipóteses similarmente reprováveis.

Nesse viés, a expressão "interpretação sistêmica", contida no título, foi utilizada com o fito de olhar para a usucapião familiar em todos os seus ângulos e pressupostos, tendo em vista os institutos envolvidos no Direito de Família e Direito das Coisas.

Este artigo se desdobrará em cinco capítulos, que trarão visões principiológicas e institucionais que gravitarão em torno da usucapião familiar. Todo este trabalho terá o propósito

2 Em autêntico rol exemplificativo, além do abandono de lar, são hipóteses de culpa pelo divórcio as subsequentes: Art. 1.573. Podem caracterizar a impossibilidade da comunhão de vida a ocorrência de algum dos seguintes motivos:

I - adultério;

II - tentativa de morte;

III - sevícia ou injúria grave;

IV - abandono voluntário do lar conjugal, durante um ano contínuo;

V - condenação por crime infamante;

VI - conduta desonrosa.

Parágrafo único. O juiz poderá considerar outros fatos que tornem evidente a impossibilidade da vida em comum. (BRASIL, 2002) 
de verificar a possibilidade de extensão de hipóteses reprováveis, na seara da usucapião familiar, para além do abandono de lar.

\section{PRINCIPIOLOGIA}

Os princípios são núcleos de pensamento, por intermédio dos quais a própria hermenêutica é estruturada. Nesse condão, a Filosofia do Direito ${ }^{3}$ dedica-se a estudar o espaço ocupado pelos princípios na Ciência do Direito. Ora, embora existam dissonâncias doutrinárias, o mais prudente é trazer ares objetivos aos princípios, em comparação com a subjetividade da moral, além da marca da exigibilidade.

Tércio Sampaio Júnior esclarece a força dos princípios nos termos subsequentes:

Os princípios, como vemos, são enunciados diretores da atividade humana juridicamente considerada. Os que mencionamos são regionais. Contudo, há princípios que valem para todos os âmbitos. São princípios gerais de direito, como o da igualdade, o da responsabilidade por danos, o de que o pactuado deve ser observado (pacta sunt servanda) etc. Em seu nome, a dogmática procura entender o direito como um todo, postulando sua unidade. Para ela, não obstante as distinções, o direito é, em última análise, um só. Daí o sentido sistematizador de sua tarefa. 0 sistema daí resultante, como vimos mostrando, pode não ser um conjunto rigorosamente lógico, mas deve manifestar certa coerência e sentido de coesão.(FERRAZ JÚNIOR, 2017, p.108)

Os princípios são parâmetros, ondas de amadurecimento do pensamento jurídico. São pilares capazes de esclarecer e iluminar a mente dos atores do direito. Desse modo, a aplicação principiológica transmite congruência e sustentabilidade interpretativa.

Para elucidar o impacto dos princípios vejamos o pensamento do jusfilosófo Miguel Reale:

Princípios são, pois, verdades ou juízos fundamentais, que servem de alicerce ou de garantia de certeza a um conjunto de juízos, ordenados em um sistema de conceitos relativos a dada porção da realidade. Às vezes também se denominam princípios certas proposições que, apesar de não serem evidentes ou resultantes de evidências, são assumidas como fundantes da validez de um sistema particular de conhecimentos, como seus pressupostos necessários. (REALE, 2002, p.60)

Portanto, os princípios trazem lucidez para o discurso ou decisão jurídica. Nesse discurso de exaltação os preceitos normativos não passam de irradiações principiológicas.

3 Foi assim com a Filosofia: ela renasceu. E a Filosofia do Direito chegou com toda sua energia de sempre. Revolucionária, já que não está presa a parâmetros quaisquer; ela voltou para libertar o pensamento jurídico. Não há Ciência do Estado, muito menos Filosofia. Não há tampouco Ciência ou Filosofia do Mercado (essa marca dos tempos atuais). A Filosofia tem de ajudar a soltar as amarras, a desvendar a ocultação trazida pela linguagem, a mostrar os limites da técnica, a ensinar a trabalhar com os princípios, a tornar claros os valores fundamentais e a ética, a gerar coragem para fazer Justiça, enfim, a produzir uma consciência do papel social relevante que todo estudante e todo operador do Direito devem ter. (NUNES, 2015, p. 18) 


\subsection{DIGNIDADE DA PESSOA HUMANA}

A dignidade da pessoa humana apresenta como irradiações: a tutela da integridade física e moral. Essas irradiações nos inclinam uma vez mais à proximidade axiológica entre a dignidade da pessoa humana e a personalidade, trata-se de uma sintonia umbilical.

Segundo Bretas e Machado: "A dignidade da pessoa humana é a fonte justificadora de todo o Ordenamento Jurídico brasileiro, o pilar sobre o qual toda estrutura normativa deve repousar." (BRETAS E MACHADO, 2018, p.60)

São espécies também basilares da dignidade, a ôntica e assistencial. A primeira das quais se refere à percepção de que a dignidade é bem jurídico, latente, inerente ao homem. Isto é, sou homem logo tenho dignidade. Lado outro, a assistencial é compreendida como a necessidade de o Estado tutelar a dignidade do homem, de modo preventivo, repressivo, extrajudicial e jurisdicional. Nessa esteira:

o valor da dignidade alcança todos os setores da ordem jurídica(...) o substrato material da dignidade desse modo entendida pode ser desdobrado em quatro postulados: i) sujeito moral (ético) reconhece a existência dos outros como sujeitos iguais a ele; ii) merecedores do mesmo respeito à integridade psicofísica de que é titular; iii) é dotado de vontade livre, de autodeterminação; iv) é parte do grupo social, em relação ao qual tem a garantia de não vir a ser marginalizado. (MORAES, 2006, p.17)

A dignidade, conforme os preceitos invocados, é considerada cláusula pétrea, portanto, protegida materialmente pelo poder constituinte originário, nos termos do artigo 60, parágrafo quarto, da vigente Constituição Federal.

A dignidade é direito personalíssimo e individual, por isso, pertence ao rol de direitos individuais, portanto, direito fundamental de primeira geração. 0 discurso é nesse sentido interligado às defesas revolucionárias (Revolução Francesa, Americana, e outras tantas), conforme Puccinelli Júnior $(2015$, p.26)

A dignidade, compreendida como direito fundamental, carrega consigo a eficácia horizontal (entre pessoas, não hierarquizada, deve haver a reciprocidade do respeito e da promoção do respeito à dignidade), vertical (o Estado deve primar pelo zelo à dignidade, similarmente ao discurso da dignidade assistencial) e irradiante (a defesa da dignidade diz respeito aos mais distintos horizontes e esferas), conforme é possível extrair da reflexão de André Puccinelli Júnior (2015, p.263-264).

\subsection{AUTONOMIA PRIVADA}

O primeiro cuidado hermenêutico a ser tomado é no sentido de identificar a morfologia mais apropriada. Isto é, não podemos confundir autonomia privada e autonomia da vontade, afinal a autonomia da vontade muito se relaciona a perspectiva de liberdade ilimitada, sem maiores interferências estatais. Por outro lado, a autonomia privada permite, de forma mais nítida, a interferência do Estado, tendo em vista o discurso da função social dos contratos, por exemplo. Vejamos: 
De forma flagrante, a autonomia privada deve ser confrontada com a autonomia da vontade. Embora saibamos que aquela apresenta limitações legais marcantes, diferentemente da autonomia da vontade, levando-se em consideração a liberdade concernente aos indivíduos, sensivelmente estudada na órbita contratual, todavia, sem a percepções de marcantes limitações legais. (BRETAS, 2015, p.127)

A autonomia privada é traduzida, em termos objetivos, como a liberdade limitada no contexto patrimonial. Este princípio tem uma série de desdobramentos, entre os quais a obrigatoriedade, intangibilidade inicial, liberdade contratual e liberdade de contratar, entre outras.

A limitação da autonomia pode se perfazer em virtude de limites convencionais e normativos. De modo categórico, a autonomia é limitada pela função social dos contratos, bem como pela própria dignidade da pessoa humana.

Segundo Perlingieri, a autonomia privada deve ser interpretada como:

a liberdade de regular por si as próprias ações ou, mais precisamente, de permitir a todos os indivíduos envolvidos em um comportamento comum determinar as regras daquele comportamento através de um entendimento comum.(PERLINGIERI, 2002, p.17)

Isso posto, a autonomia privada deve conduzir o intérprete aos patamares das liberdades contratual e de contratar. Nesse tom, devemos conceber a liberdade de modo consonante aos limites racionais normativos.

\subsection{FUNÇÃO SOCIAL DA PROPRIEDADE}

A propriedade, desde os tempos mais remotos, passou por significativas transformações. De comunal à privada. De propriedade absoluta e intangível conforme os romanos à propriedade função-social, conforme teorizado por Szaniawski, citando Léon Duguit (2000, p.32). Em outros termos, trata-se da migração da perspectiva propriedade-direito à propriedade-dever.

Fachin (1988, p.15) esclarece que, em períodos mais remotos da história, a propriedade privada representava a exacerbação do individualismo, além disso, era marcada pela inviolabilidade e pelo absolutismo. Nesse sentido, entende-se que nesse período não havia qualquer possibilidade de intervenção estatal. Uma vez que prosperava o caráter perpétuo e absoluto.

O legislador não exauriu o conceito de função social da posse e da propriedade, aliás, sua postura não foi outra senão positivar uma cláusula geral, por intermédio da qual foram instaurados parâmetros e pilares da função social, em especial o meio ambiente, nos termos do artigo 186 da Constituição da República Federativa do Brasil.

O que é decisivo quando se avalia a função social da posse e da propriedade é perceber a sua interligação profunda ao bem jurídico dignidade da pessoa humana. Nesse sentido, a partir de uma séria leitura do "Estatuto Jurídico do Patrimônio Mínimo", de Luiz Edson Fachin (2008), podemos atingir a proposição de que a dignidade é o principal elemento que compõe o patrimônio. Ora, quando falamos a respeito de patrimônio estatal, a premissa é que são componentes deste patrimônio todos os bens corpóreos e incorpóreos, e as estruturas existenciais concernentes ao seu povo. 
Desse modo, são indissociáveis a dignidade da pessoa humana e a função social, assim como, conforme o artigo 186 da vigente Constituição Federal, o uso racional do solo, o respeito ao meio ambiente e aos trabalhadores.

Nessa mesma toada dogmática, vejamos a concepção de Gonçalves:

A atual Constituição Federal dispõe que a propriedade atenderá a sua função social (art. 5o, XXIII). Também determina que a ordem econômica observará a função da propriedade, impondo freios à atividade empresarial (art. 170, III) (...) Todo esse conjunto, no entanto, acaba traçando o perfil atual do direito de propriedade no direito brasileiro, que deixou de apresentar as características de direito absoluto e ilimitado, para se transformar em um direito de finalidade social(GONÇALVES, p.241-242, 2018)

Devemos também enxergar que, conforme leciona Pietro Perlingieri (2002, p.229), a função social é elemento decisivo da propriedade, isto é, se não houver atendimento aos parâmetros da função social, essencialmente não há como reconhecer a propriedade.

\section{CONCEITOS ELEMENTARES}

Inelutavelmente o exercício interpretativo exige a construção de variáveis e de institutos. Neste trabalho, os institutos a serem confrontados são a detenção, posse e propriedade.

Importa mencionar, preliminarmente, que a expressão "possuidor" não se confunde com proprietário, posto que este carrega consigo os atributos de dispor e reivindicar a coisa em face daquele que injustamente a detenha, nos termos do artigo 1.228 do vigente Código Civil.

Possuidor também não se confunde com detentor; importa também ponderar que a posse qualificada não se confunde com a detenção, sendo certo que esta não induz a usucapião e aquela sim.

\subsection{POSSE}

A Natureza jurídica da posse sempre será tormentosa. Num primeiro momento, conforme as lições de Carlos Roberto Gonçalves (p.382, 2019) devemos compreendê-la como fática, na medida em que a materialização de seus atributos pode se dar independentemente de qualquer ajuste de desígnios. Pode ser tida também como direito, uma vez que o seu vilipêndio instaura em favor de seu legitimo destinatário uma série de mecanismos possessórios extrajudiciais, judiciais típicos e atípicos, para fins de tutela.

O certo é que nenhuma reflexão que façamos será suficientemente robusta para aquietar os ânimos doutrinários históricos. Todavia, apesar de estarmos distantes de exaurir esta questão, de antemão devemos afastar o posicionamento da posse como direito real, não obstante a sua interface e certo "umbilicalismo" com a propriedade, posto que a posse não está preceituada no aparente rol taxativo dos Direitos Reais, nos termos artigo 1.225 do vigente Código Civil de 2002. 


\subsubsection{Conceito e teorias}

No direito das coisas há a imprescindibilidade do estudo acerca de dois bens jurídicos nevrálgicos, ambos concernentes aos direitos fundamentais de primeira geração (propriedade e posse). Por outro lado, apresentamos também o relevante discurso dos direitos fundamentais de segunda geração, tendo em vista os direitos sociais.

De antemão é necessário propugnar que à luz do Código Civil de 2002, nos termos do artigo 1.196, possuidor é aquele que exerce um dos atributos de proprietário, que estão preceituados no artigo 1.228, caput, do Código Civil, isto é, trata-se daquele que exerce o(s) atributo (s) de usar, fruir e gozar da coisa.

\subsubsection{Detenção}

Entre as modalidades de detenção, emergem as subsequentes: Mera permissão ou tolerância, nos termos do artigo 1208 do Código, bem como as modalidades injustas (violência e clandestinidade, enquanto perdurarem e a precariedade).

Além destas iniciais, invoque-se o famigerado fâmulo da posse (aquele que conserva a posse em favor de terceiros. Em se tratando desta modalidade, é possível a usucapião, desde que estejamos diante do esvaziamento da subordinação), nos termos do artigo 1198 do Código Civil.

Por derradeiro, os exercícios fáticos, aparentemente possessórios sobre bens públicos, nos termos do artigo 191, parágrafo único, 183 da Constituição Federal, conforme as súmulas 619 do Superior Tribunal de Justiça, 340 do Supremo Tribunal Federal, e artigo 99 do Código Civil, não induzirão a usucapião. Assim, nos termos da súmula 340 do Supremo Tribunal Federal : Não importa a espécie de bem público, seja ele dominical, de uso especial ou comum, nenhuma destas modalidades induzirá a usucapião, "a priori".

Vislumbramos sentido jurisprudencial, ao refletir sobre a invocada súmula, posto que a usucapião é hipótese de aquisição originária, em razão do exercício possessório, trazendo um caráter tendencialmente individual (certamente de alcance inter partes em favor do usucapiente.

\section{USUCAPIÃO}

\subsection{ESSÊNCIA}

O instituto da usucapião é complexo e assume posição de centralidade no Direito das Coisas. A usucapião é instituto clássico do Direito das Coisas, consiste no meio através do qual se perfará, segundo Rizzardo (2016, p.54), a aquisição originária em favor do usuca- 
piente, transmitindo-se, em virtude do reconhecimento da posse qualificada, título hábil para fins de transmissão da propriedade.

A compreensão deste trabalho passa pela compreensão da posse. Afinal, a posse em seu condão cosmopolita, é fato e direito, bem como tem uma série de classificações, tais como simples versus qualificada, direta versus indireta, composse versus exclusiva, viciada objetivamente versus não viciada, boa-fé versus má-fé, etc.

Este trabalho exige valorações dogmáticas e axiológicas. No que tangencia a posse, o Código Civil de 2002 adota a teoria simplificada da posse, de Rudolf Von Ihering, conforme o artigo 1.196.

Conforme esta teoria, possuidor é aquele que traz consigo os atributos affectio tenedi e corpus. Pressupostos esses, que nos levam a reputar que possuidor é aquele tem a aparência de dono, isto é, estamos diante daquele sujeito que se porta com considerável zelo em relação à coisa ao ponto de se assemelhar ao proprietário, estamos diante do discurso da visibilidade, da exteriorização. Senão observemos:

Dá-se hoje o nome de 'corpus' à relação exterior da pessoa com a coisa estabelecida pela apreensão. Os juristas romanos, pelo contrário, não se serviam dessa expressão senão para designar a manifestação da vontade no ato de apreensão. 0 `corpus, segundo a teoria dominante, é o poder físico ou a supremacia de fato sobre a coisa, tal é a noção fundamental pela teoria atual. Ela é absolutamente errônea, como se pode ver em minha obra já citada: 0 fundamento da proteção possessória.(IHERING, 2002, p.43).

Por outro lado, é inequívoca a valoração, em menor grau (quando comparamos ao prestígio à Teoria de Ihering), por parte do Código Civil, da Teoria Subjetiva de Von Savigny, segundo a qual, conforme a interpretação de Gonçalves (2019, p.371), possuidor é aquele que reúne os pressupostos subjetivo ("animus domini") e objetivo (corpus: inclinando-nos ao poder do sujeito em relação coisa).

Some-se também a teoria sociológica, sustentada por autores como Silvio Perozzi, segundo Gonçalves (2019, p.374), trazendo à baila a tese de que possuidor impõe em relação à coletividade uma abstenção, promovendo um autêntico reconhecimento social.

Paulo Nader invoca a concepção sociológica nos termos subsequentes:

Correntes sociológicas, sensibilizadas pela profunda desigualdade social, que atinge grande parte dos povos e marca o início do terceiro milênio, buscam valorizar a posse como instrumento de aquisição da propriedade, enfatizando a justiça social como valor preeminente. A doutrina encontra valiosa fundamentação nos estudos do francês Raymond Saleilles. Sensível à tendência, o Código Civil, dando projeção ao princípio constitucional da função social da propriedade (art. $5^{\circ}$, XXIII), confere o domínio de área extensa, após cinco anos de posse ininterrupta e de boa-fé, a grupo considerável de pessoas que, em conjunto ou separadamente, tenha realizado obras e serviços de interesse social e econômico (art. 1.228, § $4^{\circ}$ ) (NADER, 2016, p.39)

Portanto, no direito comparado sobre posse merecem apreço as influências italiana, francesa e alemã, para fins de construção do direito das coisas no Brasil ${ }^{4}$. Ora, conforme

4 Anterior à polêmica entre Savigny e Ihering, o Code Napoléon, pelo art. 2.228, assim define o objeto de nosso presente estudo: "A posse é a detenção ou o gozo de uma coisa ou de um direito que temos ou que exercemos por nós mesmos, ou por um outro que a tem ou que a exerce em nosso nome." Aparentemente o legislador não teria distinguido posse de detenção, 
expusemos, as teorias de Savigny e Ihering são desenvolvidas na Alemanha. Noutro giro, a teoria de Silvio Perozzi foi desenvolvida na Itália. Por fim, comparativamente, não podemos ignorar o impacto "napoleônicos" na França.

Com amparo no Código Civil de 2002, nos termos do artigo 1.196, possuidor é aquele que exerce um dos atributos de proprietário, que estão preceituados no artigo 1.228, caput, do Código Civil, isto é, trata-se daquele que exerce o(s) atributo (s) de usar, fruir e gozar da coisa.

\subsection{MODALIDADES E PRESSUPOSTOS}

Múltiplas são as modalidades de usucapião, sendo certo que todas elas têm múltiplos pontos em comum. No primeiro momento devemos confrontar a usucapião sobre bens móveis versus imóveis, a primeira está preceituada no artigo 1.260 do Código Civil e que se desdobra em ordinária (exige a boa-fé e justo título, além do lapso temporal de três anos) e extraordinária (lapso temporal de cinco anos, independentemente de justo título e boa-fé). Por outro lado, as usucapiões sobre bens imóveis tem uma série de desdobramentos, que preverão lapsos variáveis entre 2, 5, 10 e 15 anos.

Independentemente da modalidade de usucapião, será imprescindível a posse qualificada, isto é, ad usucapionem, capaz de preencher a inteireza de pressupostos para fins de usucapião. Esses pressupostos revelam a imprescindibilidade de que a posse seja mansa, pacífica, ininterrupta e com animus domini.

A modalidade extraordinária: está prevista no artigo 1.238 do Código Civil, que prevê o lapso temporal aquisitivo de 15 ou 10 anos (desde que o usucapiente exerça a posse para fins de moradia ou tenha edificado obras relevantes sob a égide social ou econômica). Importa mencionar que esta modalidade não exige boa-fé, justo título, nem tampouco há limites de metragem.

Ordinária: artigo 1.242 do Código Civil, cuja prescrição aquisitiva é de 10 ou 5 anos (parágrafo único do artigo em foco). Esta modalidade exigirá boa-fé e justo título do usucapiente.

Especiais: todas essas modalidades preveem o lapso temporal de cinco anos para a aquisição originária via usucapião, valoram o elemento moradia, bem como o imóvel deve estar situado na zona urbana ou rural, por fim, os usucapientes não podem ser proprietários de outros imóveis urbanos ou rurais. De modo específico vejam os desdobramentos das modalidades especiais:

o que não é real, pois o termo detenção não foi empregado em sentido técnico, mas equivalente à apreensão. A posse é projetada como um simples fato e não como um direito subjetivo. 0 sistema admite, além da posse das coisas, a dos direitos. Com uma distinção entre posse natural e civil, o Código Civil espanhol, de 1888, pelo art. 430, conceitua a posse civil à luz da teoria subjetiva de Savigny, situando a posse natural como "a posse de uma coisa ou o gozo de um direito por uma pessoa". A diferença específica da posse civil consiste no fato de uma pessoa ter uma coisa ou desfrutar de um direito com a intenção de dono. Caracteriza-se a posse natural, ou detenção, segundo Aubry e Rau, quando "uma pessoa tem de fato uma coisa sob seu poder, sem a intenção de submetê-la ao exercício de um direito real".59 o Código Civil da Alemanha - pátria de Savigny e de lhering - não se esmerou na definição de posse (Besitz), limitando-se a dispor sobre a sua aquisição: "A posse de uma coisa é adquirida pela obtenção do poder de fato sobre a coisa..." (art. 854). Da concepção de Savigny assimilou apenas o elemento corpus. A temática da posse é desenvolvida nos demais dispositivos - art. 855 a 872. De acordo com o BGB, ter-se-á posse quando alguém praticar um poder de fato sobre uma coisa. Por força do art. 1.140, $1^{\text {a }}$ parte, o Código Civil italiano, de 1942, sufragou a teoria de Rudolf von Ihering. (NADER, 2016, p.39). 
Individual urbana (artigo $9^{\circ}$ da Lei 10.257/01, cuja metragem não pode sobejar a 250 metros quadrados),

Especial coletiva urbana (artigo 10 da Lei 10.257/01), cujo teor normativo é:

Art. 10. Os núcleos urbanos informais existentes sem oposição há mais de cinco anos e cuja área total dividida pelo número de possuidores seja inferior a duzentos e cinquenta metros quadrados por possuidor são suscetíveis de serem usucapidos coletivamente, desde que os possuidores não sejam proprietários de outro imóvel urbano ou rural. (BRASIL, 2001)

Constitucional rural ou pró-labore (artigo 191 da Constituição Federal), cuja metragem não pode sobejar a 50 hectares, desde que o imóvel esteja situado em zona rural e sirva para a moradia e labor, nos termos do artigo constitucional anteriormente mencionado.

Individual urbana familiar (artigo 1.240-A do Código Civil), cuja legitimidade concerne ao cônjuge abandonado (segundo o Conselho de Justiça Federal, o abandono exigirá simultaneamente $\mathrm{o}$ abandono da posse e da família), desde que este exerça a posse exclusiva por dois anos, em zona urbana, em imóvel que não exceda a 250 m2.

Por derradeiro, temos as de complexa materialização, quais sejam: Administrativa (Lei 13.105/15), bem como de Silvícolas (Lei 6.001/1973);

Em meio a todas essas modalidades, múltiplos pressupostos limítrofes podem ser vislumbrados, entre os quais: para se usucapir é imprescindível que a posse seja mais do que simples, mais do que ad interdicta, é necessário que seja qualificada, ad usucapionem, isto é, deve ser a posse mansa, pacífica, ininterrupta, e com o resquício subjetivo da teoria da posse de Savigny, o animus domini. Vale afirmar que é essencial que os possuidores exerçam a sua posse com intenção de propriedade, como se realmente proprietários fossem.

\section{PRESSUPOSTOS DA USUCAPIÃO FAMILIAR}

Este capítulo, de caráter derradeiro, apresentará os pressupostos usucapião especial urbana individual familiar, fruto da Lei Ordinária Federal 12.424 de 2011, capaz de inserir o artigo 1240-A, do Código Civil de 2002, segundo o qual:

Aquele que exercer, por 2 (dois) anos ininterruptamente e sem oposição, posse direta, com exclusividade, sobre imóvel urbano de até $250 \mathrm{~m} 2$ (duzentos e cinquenta metros quadrados) cuja propriedade divida com ex-cônjuge ou ex-companheiro que

abandonou o lar, utilizando-o para sua moradia ou de sua família, adquirir- Ihe-á o domínio integral, desde que não seja proprietário de outro imóvel urbano ou rural. $\S 1^{\circ} \mathrm{O}$ direito previsto no caput não será reconhecido ao mesmo possuidor mais de uma vez. (BRASIL, 2002)

Esta modalidade tem flagrante similitude com a usucapião especial urbana individual, posto que ambas são adstritas aos imóveis situados na zona urbana, assim como ambas só serão logradas se o imóvel a ser usucapido não sobejar em sua metragem o importe de 250 metros quadrados. Ainda em tom de similitude, é notório que ambas têm a restrição de que o usucapiente não poderá ter outro imóvel urbano ou rural. Todavia, o que diferencia a usuca- 
pião familiar da especial urbana individual certamente é o lapso temporal de dois anos, bem como a posse exclusiva, e o fato de exigir o abandono de lar. Por outra via, a especial urbana individual não exige abandono de lar, nem tampouco exige posse exclusiva. Por fim, o seu lapso temporal aquisitivo é de cinco anos.

O usucapiente na modalidade em foco deverá comprovar que o imóvel é aquele no qual há a moradia habitual, sendo certo que esta modalidade não poderá ser lograda mais de uma vez pelo mesmo sujeito.

Importa, portanto, situar o interlocutor que esta modalidade não é passível de retroatividade. Por isso, ficou assentado o entendimento, conforme o enunciado 498 do Conselho de Justiça Federal, de que a usucapião familiar só poderá ser vindicada a partir de 16 de Junho de 2013.

Merece especial guarida o pressuposto do abandono, para fins de usucapião na modalidade em voga. Preliminarmente, esta modalidade jamais deve ser reputada absurda, pois antes mesmo da superveniência da usucapião familiar, o artigo 1.275 do Código Civil de 2002 já previa que o abandono é hipótese de perda da propriedade.

Segundo Farias e Rosenvald (2017):

Tal e qual aquilo que dispõe o caput do art. 1.240 do Código Civil, a metragem máxima do imóvel será de $250 \mathrm{~m} 2$. Com o abandono do lar pelo biênio, o ex-cônjuge ou ex-companheiro que permaneceu no imóvel pleiteará a usucapião da parte imóvel que não lhe pertencia, sendo que a procedência da pretensão determinará uma nova forma de extinção da compropriedade, diversa das que são preconizadas no direito de família; (FARIAS E ROSENVALD, p. 461, 2017)

Merece ainda extremado apreço a interpretação do Conselho de Justiça Federal em relação ao instituto, segundo o qual a usucapião familiar não implica discussão sobre culpa pelo divórcio. Nesse interim, não há que se discutir culpa nesta modalidade de usucapião, motivo pelo qual emerge o enunciado 595 deste Conselho, que revogou o enunciado 499:

0 requisito 'abandono do lar' deve ser interpretado na ótica do instituto da usucapião familiar como abandono voluntário da posse do imóvel somado à ausência da tutela da família, não importando em averiguação da culpa pelo fim do casamento ou união estável. (...) (TARTUCE, 2018). ${ }^{5}$

É perceptível ainda que para a configuração do abandono, para fins de usucapião familiar, exigível será o abandono do imóvel, bem como da própria família ${ }^{6}$, sendo decisiva a observância de circunstâncias do caso concreto. Nesse sentido:

O cônjuge ou companheiro do usucapiente há de ter abandonado o lar. 0 abandono se caracteriza pelo desamparo. 0 cônjuge ou companheiro saem

5 TARTUCE, Flávio. Divulgação oficial dos enunciados aprovados na VII Jornada de Direito Civil em Setembro de 2015. Disponível em: https://flaviotartuce.jusbrasil.com.br/noticias/247806230/divulgacao-oficial-dos-enunciados-aprovados-na-vii-jornada-de-direito-civil-em-setembro-de-2015. Acesso em 18 de dezembro de 2018.

6 Família na definição de Rodrigo da Cunha Pereira tem conotação amplíssima, sob a égide conjugal ou não, fruto de fertilizações naturais ou não, etc: Um gênero que comporta duas espécies, em sua constituição: a família conjugal e a família parental. A conjugal é aquela que se estabelece com base em uma relação amorosa, envolvendo sexualidade e pode advir daí filhos, ou não. Pode ser heteroafetiva ou homoafetiva, pelo casamento ou união estável, simultânea à outra, quebrando o princípio da monogamia, ou não; a família parental é aquela que decorre da formação de laços consanguíneos ou socioafetivos. Pode ser por inseminação natural ou artificial, geradas em um útero próprio ou de substituição (barriga de aluguel). Seja como for, parental ou conjugal, interessa ao Direito de Família a inclusão de todas essas novas configurações para que se possa atribuir direitos e receber proteção do Estado. (PEREIRA, 2018, p.288) 
de casa, deixando seu consorte e/ou filhos ao desamparo, sem sua contribuição, sem sua presença física. 0 fato de o cônjuge ou companheiro sair de casa, mas continuar contribuindo, não configura abandono. (FIUZA, p.982, 2014)

Conforme expusemos nos capítulos pretéritos, além dos pressupostos específicos, será necessário, o "animus domini" e que a posse seja mansa, pacífica e ininterrupta. Além disso, precisamos nos atentar para a morfologia das palavras "ex-cônjuges" e "ex-companheiros", contidas no artigo 1.240-A. Nessa toada semântica, só se configura ex-cônjuge ou ex-companheiro se já tiver havido a dissolução do vínculo conjugal ou de união estável, razão pela qual a mera separação de fato não dissolveria o vínculo conjugal, portanto, não poderia configurar a usucapião familiar, em uma visão literal.

A separação de fato, embora, por si só, não seja capaz de dissolver o vínculo conjugal, pode preencher um dos requisitos da usucapião familiar. Senão vejamos: Imaginemos que Fernanda seja casada com Josué, e que ambos são casados no regime legal (comunhão parcial de bens), conforme a Lei 6.515/1977, e que o casal adquiriu um imóvel na constância do casamento. A partir dessas informações, nos termos do artigo 1.658 do Código Civil, o referido imóvel é de propriedade de Fernanda e Josué. Dessa forma, caso Fernanda abandone o lar e Josué perdure por mais de dois anos na posse exclusiva do imóvel, cumulado com os outros pressupostos anteriormente analisados, não há como negar que houve separação de fato, todavia, ambos ainda figuram na condição de cônjuges (isto é, ainda não são ex-cônjuges, como morfologicamente o artigo 1.240-A está a exigir), e, apesar disso, não propugnamos, nos termos narrados, quaisquer óbices para que Josué logre a usucapião familiar. Por esta razão, cremos que cabível é a interpretação extensiva ${ }^{7}$ em relação ao dispositivo, em virtude do fato de que a usucapião familiar tanto é cabível entre cônjuges ou companheiros, que estejam separados de fato, conforme o enunciado $501^{8}$ do Conselho de Justiça Federal, sendo certo que o ponto nuclear será a configuração do abandono, que se dá por conta do abandono do imóvel, bem como o abandono da própria família, verificando-se se houve o desamparo familiar.

Conforme as mais distintas fontes do Direito, a hipótese geradora da usucapião familiar é adstrita ao abandono. Todavia, o abandono no âmbito civilista familiar gera qual efeito historicamente? ${ }^{9} \mathrm{~A}$ culpa pelo divórcio, cuja discussão está preponderantemente suavizada em termos de entendimento (posto que resplandece o pensamento de que a culpa pelo divórcio, por conseguinte a Emenda Constitucional 66 de 2010, não tem mais qualquer sentido), tornando-se inócua ${ }^{10}$ para o Direito de Família, apesar de não haver qualquer dispositivo normativo explicitamente abolicionista. Nesse mesmo viés:

7 Aliás, similar é o nosso entendimento no tocante a possibilidade de extensão da usucapião familiar na seara rural.

8 As expressões "ex-cônjuge" e "ex-companheiro", contidas no art. 1.240-A do Código Civil, correspondem à situação fática da separação, independentemente de divórcio.

9 Ao discutir o reflexo da culpa no contexto da usucapião familiar: Via de consequência, ao inserir dentre os requisitos da usucapião o abandono voluntário e injustificado do lar por parte de um dos cônjuges ou companheiros a Lei número 12.424/11 aparentemente resgata a discussão da infração aos deveres do casamento e união estável. Vale dizer, em detrimento da liberdade e da constatação do fim da afetividade, avaliar-se-ia a culpa e a causa da separação, temáticas que haviam sido abolidas pela referida EC cuja eficácia é imediata e direta, não reclamando a edição de qualquer norma infraconstitucional. Se as normas anteriores à EC n' 66; 10 não mais são recepcionadas pelo ordenamento, certamente as posteriores- como a que ora se discute - podem ser reputadas ineficazes perante a ordem constitucional. Mais coerente com uma visão constitucional, será interpretar à exigência do abandono, como uma omissão do dever fundamental de convivência familiar (art. 227, CF) por parte daquele genitor que se ausentou do lar. (FARIAS, ROSENVALD, p. 461, 2017)

10 Com culpa ou sem culpa, com tempo de convivência ou sem tempo de convivência nada obsta o divórcio, em verdade ainda são cabíveis os danos morais entre cônjuges. 
Com efeito, se o abandono do lar não é mais fundamento jurídico para o divórcio na medida em que este direito é essencialmente potestativo e dispensa causa específica declarada, por outro lado, poderá resultar no reconhecimento da usucapião em favor do cônjuge ou companheiro que permaneceu no imóvel do casal, exercendo posse mansa, pacífica e com animus domini (GAGLIANO, PAMPLONA FILHO, p. 1012, 2017)

Nesse contexto, o abandono está acompanhado, conforme o artigo 1.573, de outras tantas hipóteses:

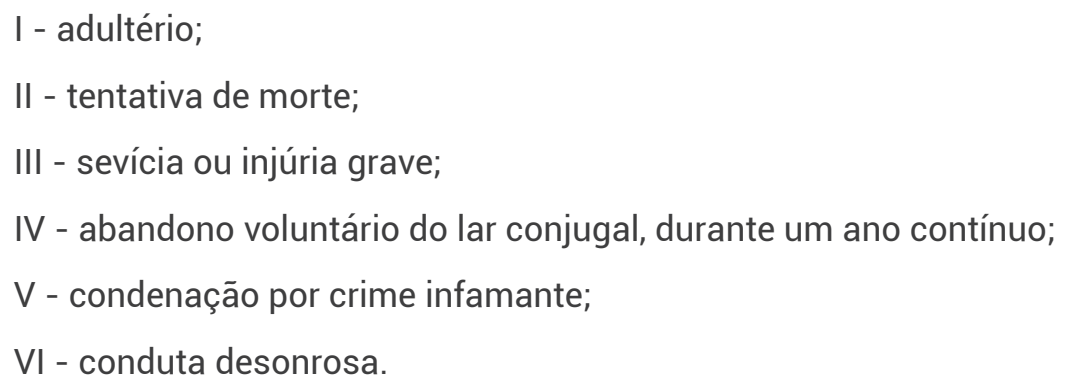

Parágrafo único. 0 juiz poderá considerar outros fatos que tornem evidente a impossibilidade da vida em comum. (BRASIL, 2002)

Por esta razão, o legislador no artigo 1.240-A do Código Civil de 2002 estabeleceu uma única hipótese geradora de usucapião familiar. Assim, a partir de uma inelutável sistêmica entre o invocado artigo e o artigo 1.573 deste diploma, não vislumbramos óbices para a extensão das hipóteses geradoras de usucapião familiar.

\section{CONSIDERAÇÓES FINAIS}

Após todo o percurso interpretativo trilhado, reputamos que a usucapião familiar de fato experimentou complexas dissonâncias doutrinárias e jurisprudenciais. Em verdade, o legislador, em sua ríspida ratio legis, foi feliz ao trazer esta nova modalidade de usucapião, na medida em que a conduta de abandono de lar entre companheiros ou cônjuges merece ser tutelada de modo diferenciado, posto que revela o descumprimento de um dever conjugal, além de gerar em favor do abandonado, congruentemente, animus domini e a possibilidade de exercer a posse exclusiva. Aliás, a tutela em relação à usucapião familiar, deu-se do modo mais típico do Direito Civil, isto é, por meio de um reflexo patrimonial. Nesse teor, o cônjuge ou companheiro abandonado se tornará, em sua inteireza, proprietário do imóvel que tinha em condomínio com o seu consorte, o "abandonador".

Amparado nesta razão legislativa, o Conselho de Justiça Federal estabelece que o abandono, para fins de usucapião familiar, se dará por meio do cúmulo do abandono da posse do imóvel a ser usucapido e o abandono da família, tendo em vista a observância do desamparo. Nesse sentido, a usucapião familiar valora a seara do desligamento possessório do cônjuge ou companheiro, bem como repudia a conduta de abandono da própria família.

De modo que, se o abandono da família também é relevante para a configuração da usucapião familiar, sistemicamente vislumbramos que, ao mergulharmos na aludida "ríspida razão legislativa", existiriam outras hipóteses (igualmente consideradas no âmbito do Direito 
de Família), preceituadas no artigo 1.573 do Código Civil em vigor, que poderiam gerar a usucapião familiar. Assim, o adultério, crime infamante, lesão corporal, tentativa de homicídio, estão previstas no mesmo suporte fático abstrato que preceitua o abandono (artigo 1.573 do Código Civil de 2002), sendo certo que todas elas são hipóteses historicamente e similarmente gravosas no âmbito conjugal.

Portanto, tentamos promover um encontro hermenêutico entre o Direito de Família e o Direito das Coisas, a partir de dois institutos nevrálgicos: o casamento e a usucapião. A partir de tal encontro, acompanhado do zelo interpretativo que tivemos, ao tentar alcançar a mens legis peculiar ao artigo 1.240-A, posicionamo-nos favoráveis a inserção de outras hipóteses do artigo 1.573 do Código Civil vigente, para a configuração da usucapião especial urbana individual familiar.

\section{REFERENCIAS}

BRASIL. Lei n 10.406 de 10 de janeiro de 2002. Institui o Código Civil (de 10 de janeiro de 2002). Diário Oficial da União, Brasília, 2 jan. 2002.

BRASIL. Lei n 13.105, de 16 de março de 2015. Institui o Código de Processo Civil. Diário Oficial da União, Brasília, DF, 17 março 2015. Disponível em https://www.planalto.gov.br/ccivil_03/_ato2015-2018/2015/lei//13105. Acesso em: 15 dez. 2018.

BRETAS, Hugo Rios. Lições Introdutórias Didáticas de Direito: Política e Instituições de Direito. 2. ed. Rio de Janeiro: Multifoco/Luminária Academia, 2015.

BRETAS, Hugo Rios. MACHADO, Ana Maria Alves. LINDB COMENTADA: Teoria Aplicada (incluída a Lei 13.655 de 2018). 1. ed. Rio de Janeiro: Multifoco, 2018.

FACHIN, Luiz Edson. A função social da posse e a propriedade contemporânea: uma perspectiva da usucapião imobiliária rural. Porto Alegre: Fabris, 1988.

FACHIN, Luiz Edson . Estatuto Jurídico do Patrimônio Mínimo. 2. ed. Rio de Janeiro. Renovar, 2008.

FARIAS, Cristiano Chaves de. ROSENVALD, Nelson. Curso de direito civil: direitos reais. 13. ed. rev. ampl. e atualizada. Salvador: JusPodivm, 2017.

FERRAZ JÚNIOR, Tércio Sampaio. Introdução ao estudo do Direito. 10. ed. São Paulo: Atlas, 2017.

FIÚZA, César. Direito Civil: Curso Completo. 17 ed. Belo Horizonte: Del Rey, 2014.

GAGLIANO, Pablo Stolze. PAMPLONA FILHO, Rodolfo. Manual de Direito Civil: volume único. São Paulo: Saraiva, 2017.

GONÇALVES, Carlos Roberto. Direito Civil 2: Contratos em Espécie, Direito das coisas.. 7. ed. São Paulo: Saraiva Educação, 2019.

GONÇALVES, Carlos Roberto. Direito civil brasileiro, volume 5: direito das coisas. 13. ed. São Paulo: Saraiva, 2018. IHERING, Rudolf von. Teoria simplificada da posse. Belo Horizonte: Líder, 2002.

MORAES, Maria Celina Bodin de. O Princípio da Dignidade Humana. In: MORAES, Maria Celina Bodin de. (Org.). Princípios do Direito Civil Contemporâneo. v. 1. Rio de Janeiro: Renovar, 2006.

NADER, Paulo. Curso de direito civil, volume 4: Direito das Coisas. 7. ed. rev. atual. e ampl. Rio de Janeiro: Forense, 2016.

NUNES, Rizzato. Manual de filosofia do direito. 6. ed. rev. e ampl. São Paulo: Saraiva, 2015. 
Hugo Rios Bretas

PEREIRA, Rodrigo da Cunha. Dicionário de direito de família e sucessões - Ilustrado. São

Paulo: Saraiva, 2017.

PERLINGIERI, Pietro. Perfis do direito civil. Trad.: Maria Cristina De Cicco. 3. ed. Rio de Janeiro: Renovar, 2002.

PUCCINELLI JÚNIOR, André. Curso de Direito Constitucional. 5. ed. São Paulo: Saraiva, 2015.

REALE, Miguel. Filosofia do Direito. 20. ed. São Paulo: Saraiva, 2002.

RIZZARDO, Arnaldo. Direito das coisas. 8. ed. rev, atual. e ampl. Rio de Janeiro: Forense, 2016.

SZANIAWSKI, Elimar. Aspectos da propriedade imobiliária contemporânea e sua função social. Revista de Direito Privado, São Paulo, v. 1, n. 3, p.126-156, jul./set. 2000

TARTUCE, Flávio. Divulgação oficial dos enunciados aprovados na VII Jornada de Direito Civil em Setembro de 2015. Disponível em: https://flaviotartuce.jusbrasil.com.br/noticias/247806230/divulgacao-oficial-dos-enunciados-aprovados-na-vii-jornada-de-direito-civil-em-setembro-de-2015. Acesso em 18 dez. 2019.

Recebido/Received: 19.05.2019.

Aprovado/Approved: 08.06.2020. 